\title{
MISLEADING ADVERTISING: ITS CONTROL
}

\author{
JUDITH WAYNE LEE SWAN*
}

The central role that advertising plays in today's economy makes the control of misleading advertising central to any consumer protection scheme. Misleading advertising is controlled both through legal measures and extralegal organizations such as the Canadian Advertising Advisory Board. The writer of this article details existing legislation in this area, dealing particularly with sections $33 C$ and $33 D$ of the Combines Investigation Act, and considers the extent to which these laws, together with the extra-legal organizations, can successfully suppress false and misleading advertising.

Over the past century, advertising has become the sine qua non of the manufacturer-retailer-consumer relationship. Without it, the manufacturer or retailer could not inform the buying public of his goods and services, nor could the consumer make an intelligent comparison, and hence choice, of the product he wishes to purchase. Without advertising, newspapers would be much more expensive, political campaigning would flounder, and charitable causes would not be as successful. Despite this patent need for advertising, it has been accused of being too wasteful by the thrifty consumer. He must remember, however, that while some of his criticisms may be well appointed, without any advertising the manufacturers would probably spend more money on the other selling factors-e.g. salesmen or displays-and push the price of the products up even further. The advertising industry is, therefore, an essential and powerful tool of the marketing scheme. ${ }^{1}$

With such an important and visible position in all marketing activities, the activities of advertising are also the sine qua non of all consumer protection schemes: ${ }^{2}$

The size of the (advertising) industry; its central role in today's economy; its crucial role in the mass media...: and its general pervasiveness all dictate that advertising be one of the first areas considered in any attempt to deal in consumer protection.

The "central role in today's economy" mentioned in the above reference constitutes another telling argument for the efficacy of advertising in the nation's development. It creates a demand for products, thus encouraging manufacturers to use mass production methods which result in lessening the price to the consumer, who will then have a higher standard of living because he can afford the mass-produced product. It should be borne in mind, however, that although the creation of a demand for products and services generally acts as a boost to the economy, advertising also creates a demand for useless products upon which the lower income consumer would unnecessarily squander his welfare cheque, being convinced by the advertising that he cannot do without the touted product.

\section{DEVELOPMENT OF ADVERTISING AND ITS POTENTIAL FOR DECEPTION}

The development of advertising began with sporadic advertising campaigns early in the 17th century, although its exact origin is un-

- B.A. (McGill), LL.B. (Alta.).

1 For a detailed look at the breakdown in advertising, see Blackman, Advertising and Competition, (1967).

2 Pollay, Deceptive Advertising: Consumer Behaviour: A Case of Legislative and Judicial Reform, (1968-69) 17 U. of Kan. L. Rev. 625. 
known. ${ }^{3}$ It picked up during the 18th century, and in the 19th century became quite blatant, directing its messages to all social and economic classes by means of newspapers, periodicals and posted bills. ${ }^{4}$ In the 20th century, subtlety evolved from the previous blatancy so that caveat emptor has been replaced by caveat venditor. ${ }^{5}$

To demonstrate the growth rate of advertising in the 20th century, one only has to compare the increased amount of money spent in this industry. In the United States, the total yearly expenditure for advertising has gone from $\$ 300$ million in 1880 to $\$ 9,000$ million in $1955,{ }^{6}$ while in Canada today two cents out of every dollar's worth of goods and services goes to advertising. ${ }^{7}$ The Canadian advertising industry employs approximately 30,000 women and men in its four main components: advertisers, advertising agencies, media and advertising service and supply companies. ${ }^{8}$

In light of the enormity of the subject, it is extremely important to consider its inherent potential for deception. A modern day view of this potential is given in the following description: ${ }^{9}$

Advertising now utilizes numerous forms of psychological persuasion to market products. The consumer is urged to purchase the product, not because of its intrinsic value, but because of an image the product conveys. Modern persuasive advertising provides a far greater potential for deception than purely informative advertising, and the deception is more difficult to detect.

The problem of deceptive, or misleading advertising has thus been brought out, and attached to it is the consequent problem of fixing controls while preserving the advertiser's right to communicate with the public.

The first problem-that of the deceptive advertising itself-requires an attempt to define deception. This is no little task, for a study ${ }^{10}$ has shown that as among groups of housewives, students and retailers, no agreement could be reached on what constitutes deceptive advertising. Even the Minister of Consumer and Corporate Affairs, Hon. R. Basford, was at a loss to singlehandedly come up with a definition of "misleading" when contemplating the addition of section $33 \mathrm{D}$ to the Combines Investigation Act: ${ }^{11}$

This is quite a problem. This is why we are trying to work out guidelines of our

definition of 'misleading'. We will consult with industry on these guidelines. We don't consider ourselves judges of good taste. We are concerned with factual information.

Augmenting this semantic problem are the recognition of "puffing", a practice which can be described as an overly enthusiastic and biased representation of the puffer's product; and the practice of the copy writer who utilizes the Gestalt effect wherever he can. ${ }^{12}$ 'This effect

${ }^{3}$ Charlton, Fawcett, The F.T.C. and False Advertising, (1968-69) 17 U. of Kan. L. Rev. 599.

4Id. See also, particularly for illustrated examples of late 19th century-early 20th century advertismenta, Pease, Responsibilities of American Advertising, (1958).

S Morse, A Consumer's View of the Regulation of Advertising. (1968-69) 17 U. of Kan. L. Rev. 639; Also D.I.R. Report, (1968-69) at 52.

- Pease, supra, n. 4 at 12.

'Advertising Today, pamphlet published by the Canadian Advertising Advisory Board.

- Id.

- Charlton, Fawcett, supre n. 3 at 600.

10 Kotiman, A Sematic Eualuation of Misleading Advertising, (1964) 14 J. Communication 151.

1" Financial Post, 9 Novernber 1968 at A-55.

12 See speech by D.W.H. Henry. Q.C., Director of Investigation and Reseanch under the Combines Investiga. tion Act at Toronto. Ontario, 12 November 1969: "I often tell my law students that a criminal statute is only really effective to the extent that the public accepts and supports it. As I see it, the consuming 
is identifiable wherever it can be said that the whole is greater than the sum of its parts. In other words, a skilled copy writer, without blatantly lying, can put together an advertisement composed of perfectly true, individual statements; yet taken together as a whole, they give the reader a misleading impression. Further to this practice of using the Gestalt effect, it should be noted that while discussing the recent Casino Cigarettes incident in Alberta (where the said cigarettes reneged on their offer to pay a large sum of money to whomever found certain coupons inside their packages, and which now has been set down for trial following a preliminary inquiry) Mr. Dan Mazanowski, M.P., described this effect in the House of Commons:13

The problem I wish to raise is posed by certain forms of advertising and sales promotion which tend to mislead consumers. The majority of these advertisements and promotional stunts may be so carefully phrased as to be within the limits of legality. However, regardless of how they are worked and presented to the public, the end result is to mislead the consumer in varying degrees.

The effect thus described has not gone unnoticed by jurists: ${ }^{14}$

Jurists have recognized that the problem of deceptive advertising does not have the simple solution of merely demanding that statements be literally true.

The problem of the definition of "deceptive", or "misleading" advertising is, as illustrated, a complex one. The Canadian Code of Advertising Standards, prepared by the Canadian Advertising Advisory Board, in its False or Misleading Advertising section, says the following: ${ }^{15}$

No Advertisement shall be prepared, or be knowingly accepted, which contains false, misleading, unwarranted or exaggerated claims-either directly or by implication. Advertisers and advertising agencies must be prepared to substantiate their claims.

Thus, although this is not a statutory definition, it is one which should not be ignored because of the constitution and membership of the organization presenting it, ${ }^{16}$ and it indicates that "false" and "misleading" should be read together with, and defined in light of "unwarranted" and "exaggerated".17 At the end of the Code is a special note which attaches objective definitions to the foregoing sections so that misleading advertising is done on a 'reasonable man' basis. It is submitted that this is good sense when applied to statutory law; i.e., that when an ambiguous or no definition is given for "misleading", the courts should interpret it objectively.

The second problem is, as previously stated, how the consumer can be protected from deceptive advertising while, at the same time, protecting the rights of the advertisers. Or, if a balance cannot be struck,

\footnotetext{
public has for a very long time been extremely tolerant of advertising practices which tend to mislead. The result has been a sort of consumer permissiveness which has led advertisers to think that they can get away with exagserated claims, half-truthe, distortions, subliminal untruth and alike. These have come to be rationalized in the minds of even leading firms who regand themselves as entirely ethical on the grounds that they are mere puffery, that you cannot successfully promoto by telling all the facte, that grounds that they are mere puffery, that you cannot successfully promoto by telling all the facto, that competitors are doing it one must do likewise or lose ground in the market."

13 Hansard, 22 Jan. 1970 at 2863.

14 Pollay, supra, n. 2 at 626.

15 This can be found in the advertising Standards Code of the Board. N.B.: The Combines Investigation Act, a. 33D(1), offers no definition of "misleading" although 33D(2) indicates that it would be misleading to advertise a guarantee of a product without basing the statements on a proper test.

16 Extra-legal Organizations, infra, at 326.

17 Although this is, as stated, not statutory or case authority, the interpretation, aside from being suggested by the "good conscience" of the advertising industry, is plain common sense.
} 
which interest should be safeguarded to a greater extent...the consumer's or the advertiser's?

The conservative view-i.e., that the advertisers should not be strictly controlled-is given by an American who is chagrined that the F.T.C., given enough funds, would have the power to prosecute at will. ${ }^{18} \mathrm{He}$ appeals for the F.T.C. to change its standard for prosecution which merely requires the ad to have the capacity to deceive; he would prefer absolute proof that the advertisement in question does in fact deceive. His plan is as follows: ${ }^{19}$

Both the proportion of consumers misperceiving and the magnitude and consequences of their misperception will have to be assessed. The final judgment will eventually be the difficult problem of striking a balance between the potential social cost resulting from the misperceptions of some consumers and the potential social gain resulting from effective undistorted communication of information from the advertiser to the balance of the consumers.

This is obviously a cumbersome and extravagant plan. Were the F.T.C. to expend enough money to pay for the cost of finding the proportion of consumers misperceiving, there simply would not be enough funds left over for prosecuting many offenders-and the budget already is woefully small. (It is of interest that while the federal government in the United States grants an annual operational sum of approximately $\$ 14$ million to the F.T.C., Proctor \& Gamble spent $\$ 24$ million to introduce yet another phosphate-ridden detergent: Bold.20 Compare with the total U.S. expenditure for advertising in 1966-\$16.8 billion. ${ }^{21}$ )

Happily, the Canadian Government does not take the conservative viewpoint. It believes in stricter controls of advertising in order to protect the consumer. That is the reason given by $\mathrm{Mr}$. Basford to explain why section $33 \mathrm{D}$ of the Combines Investigation Act ${ }^{22}$ was transferred from the Criminal Code to the above named Act: ${ }^{23}$

so that I can have direct administrative responsibility for it.

The reason Mr. Basford wanted direct administrative responsibility, of course, is that there were no significant prosecutions under section 306 of the Criminal Code, the former but identical misleading advertising section, and he wanted tighter controls. Justice Minister Turner echoed this when he introduced the amendment into the House for changing the section over to the Combines Investigation Act: ${ }^{24}$

I cannot resist saying that the consumer has a fundamental right to correct information and that truth in advertising is essential to any charter for the consumer. I hope these amendments will more effectively protect the consumer's right to correct information in future. The Minister of Consumer and Corporate Affairs... and I intend that there shall be vigorous enforcement of these provisions on a national basis.

Therefore, it seems that the Canadian government advocates the right of the consumer to protection and the duty of the advertiser to disseminate correct information. In this sense, the advertiser is not

\footnotetext{
18 Pollay, supra, n. 2 at 629.

19 Id. at 637.

20 Morse, supra, n. 5 at 644.

21 (1968) Statistical Abstract of the U.S., 782.

22 R.S.C. 1952 , c. 314 , amended $1953-54$, c. 51 , s. 750 ; 1959 , c. $40 ; 1960$, c. 45 ; $1960-61$, c. $42 ; 1962-63$, c. 4 ; 196465 , c. 35; $1966-67$, c. 23 , c. 25 , s8. 38,$45 ; 1968-69$, c. 38, s. 116.

23 Hansard, 12 December 1968, at 3900.

24 Hansard, 23 January 1969, at 4723-24.
} 
restricted from his right of communicating with the public, as long as he does not deceive the consumer.

\section{THE LAW OF DECEPTIVE ADVERTISING}

In light of the history and policy questions discussed, references will now be made to the Canadian law of misleading advertising. As previously mentioned, section 306 of the Criminal Code contained provision for misleading advertising, but no significant cases have been brought under it. ${ }^{25}$ That section was transferred to the jurisdiction of the Combines Investigation Act and became section 33D of said act, effective 31 July $1969,-$ and is as follows:

33U. (1) Every one who publishes or causes to be published an advertisement containing a statement that purports to be a statement of fact but that is untrue, deceptive or misleading or is intentionally 80 worded or arranged that it is deceptive or misleading, is guilty of an indictable offence and is liable to imprisonment for five years, if the advertisement is published

(a) to promote, directly or indirectly, the sale or disposal of property or any interest therein, or

(b) to promote a business or commercial interest.

(2) Every one who publishes or causes to be published in an advertisement a statement or guarantee of the performance, efficacy or length of life of anything that is not based upon an adequate and proper test of that thing, the proof of which lies upon the accused, is, if the advertisement is published to promote, directly or indirectly, the sale or disposal of that thing, guilty of an offence punishable on summary conviction.

(3) Subsections (1) and (2) do not apply to a person who publishes an advertisement that he accepts in good faith for publication in the ordinary course of his business.

(4) For the purposes of subsection (2), a test that is made by the National Research Council of Canada or by any other public department is an adequate and proper test, but no reference shall be made in an advertisement to indicate that a test has been made by the National Research Council or other public department unless the advertisement has, before publication, been approved and permission to publish it has been given in writing by the President of the National Research Council or by the deputy head of the public department, as the case may be.

(5) Nothing in subsection (4) shall be deemed to exclude, for the purposes of this section, any other adequate of proper test.

As of last November 19th no information was forthcoming regarding the inquiries being taken under that section. On that day the following questions and answers appeared on the Order Paper: ${ }^{26}$ Mrs. MacInnis:

1. Which test cases are presently being prepared by the Department of Consumer and Corporate Affairs regarding misleading advertising in Canada under section 306 of the Code?

In view of the lack of jurisprudence relating to section 33D of the Combines Investigation Act, and its predecessor, section 306 of the Criminal Code, virtually every case under inquiry by the Director of Investigation and Research which reaches the Courts will be a test case. It is the practice that no information is given out as to inquiries being pursued with respect to a particular companies or individuals unless and until a report is published or proceedings are instituted in the courts.

2. On what basis is each of these cases being prepared?

Inquiries under section 33D of the Act are instituted by the Director of Investigation and Research whenever he has reason to believe that an offence against the section has been committed.

${ }^{25}$ The reluctance of the Attorney-General to prosecute this section may have been because of the uncertainty as to the amount of proof needed to secure a conviction.

so Hansard, 19 November 1969, at 986. 
As is the case with many other areas of law, the law of misleading advertising is diverse and cannot be pinpointed only under section 33D, of which more will be said later. One must also look to the common law of passing-off and various other statutes.

Kilgour ${ }^{27}$ refers to misleading advertising from the point of view that it is unethical and should give competitors the right to a private remedy. He ignores the remedies of the consumer, and only covers two areas of law: the common law of passing-off and the Trade Marks Act. ${ }^{28}$

Much of the common law authority comes from the English Courts and, as in J. Bollinger et al. v. Costa Brava Wine Co. Ltd. ${ }^{29}$ states that in a passing-off case, there is no action unless the plaintiff can prove the defendant's intent to deceive. ${ }^{30}$ An Ontario Supreme Court case $^{31}$ reprinted in the above noted casebook was slightly different from the ordinary passing-off case. There it was held that the plaintiff, an expert organ-maker, was not injuriously affected by testimonials published by the defendant company which, by omission or change of certain words, deprived the plaintiff of commendation contained in the original testimonials. Other authors have suggested that different actions in common law can be, but are seldom brought. ${ }^{32}$ These are the actions in tort for deceit or negligence or in contract for breach of warranty. However shaky these grounds may seem, especially in comparison with the statutory provisions of section 33D, they should not be overlooked.

There is little else in the common law which protects the consumer or competitor from misleading advertising, and in any event it would not be reasonable to pursue the common law provisions to a great extent since various other legislative provisions, infra, cover the field.

Of these legislative provisions, the Trade Marks Act ${ }^{33}$ is perhaps the most comprehensive. It provides in section 7 that:

7. No person shall

(a) make a false or misleading statement tending to discredit the business, wares or services of a competitor;

(b) direct public attention to his wares, services or business in such a way as to cause or be likely to cause confusion in Canada, at the time he commenced so to direct attention to them, between his wares, services or business and the wares, services or business of another;

(c) pass off other wares or services as those ordered or requested;

(d) make use, in association with wares or services, of any description that is to mislead the public as to

(i) the character, quality, quantity or composition,

(ii) the geographical origin, or

(iii) the mode of the manufacture, production or performance

of such wares or services, or

(e) do any other act or adopt any other business practice contrary to an honest industrial or commercial usage in Canada.

Section $7(a)$, having its roots in the common law tort of injurious

${ }^{27}$ Kilgour, Cases and Materials on Unfair and Restrictive Trade Practices at 74.90.

28 S.C. $1952-53$, c. 49.

20 [1960] Ch. 262

30 For other similar passing-off cases in Kilgour's text, see 81-89.

31 Warren v. D.W. Karn Co. (1907) 15 O.L.R. 115 (S. C. Ont.).

32 See Charlwn and Fawcett, supra, n. 3 at 61:3.

ss S. C. 1952-53, c. 49. 
falsehood, requires that a competitor's wares, business or services be discredited and that the statement be either false or misleading. Section 33D of the Combines Investigation Act is somewhat wider: in that the statement need merely be untrue, deceptive or misleading; no detrimental effect on the competitor need be shown. If there was detriment to the competitor, however, it would be wise to bring an action under the Trade Marks Act because of the wide powers which the court possesses to grant relief under that act. ${ }^{34}$

$7(b)$ is the subsection under which most of the litigation under section 7 is brought. Together with $7(\mathrm{c}), 7(\mathrm{~b})$ constitutes the passingoff provisions in the Trade Marks Act. The test to determine whether subsection (b) is applicable has been decided in the Exchequer Court in 1959 to be whether or not the act or practice of the defendant was likely to cause confusion. ${ }^{35}$ The Supreme Court of British Columbia in 1966 said essentially the same thing, but in greater detail. It was held that the passing-off test was not whether the buyer might possibly have been misled by the packaging, but whether a buyer with reasonable apprehension and proper eyesight would in fact be deceived. ${ }^{36}$ Infringements of $7(\mathrm{~b})$ have been held to include packaging, ${ }^{37}$ and the action is maintainable against any kind of business (not merely a business of the same general character) ${ }^{38}$ no matter whether that business concern is registered under the Act. ${ }^{39}$ This section has, therefore, been interpreted broadly and covers most passing-off actions.40

Section 7(d) requires that the description be false and misleading as to certain specific things. However, the use of the Gestalt effect would produce only misleading descriptions and liability would be avoided under this section because the ad would not be false. Its efficacy, therefore, would be mitigated (particularly keeping in mind the shrewdness of some contemporary copy writers) and the most a competitor could do would be to institute prosecution under section 33D.

Section 7(e) seems to be a catch-all section, and unless the court would interpret it broadly, is of little real value.

Other statutory provision against deceiving the public, while not specifically referring to advertising but implying that it is covered, is found in the Dominion and provincial Companies Acts. ${ }^{41}$ Both provisions are directed against passing-off activities.

The Criminal Code, in section 351 , also makes provision against any passing-off activity.

Section 14 of the Precious Metals Marketing Act ${ }^{42}$ states that in any advertisement of an article, it is an offence to use any mark or descrip-

\footnotetext{
34 See section 52 in the Act: it can award damages, give an injunction, and determine what to do with respect to the disposition of any offending wares, packages, labels and advertising material and of any, dies used in connection therewith. Under the Combines Investigation Act, however, the accused would merely be prosecuted and fined, and an injunction would, in some cases, be granted.

3s Dominion Motors Ltd. v. Gillman [1959] Ex. C. R. 423.

20 Prairie Maid Cereals Ltd. v. Christie Brown's Co. Ltd. (1966) 56 W.W.R. 375.

${ }^{3}$ Canadian Converters' Co. Ltd. v. Eastport Trading Co. Ltd. (1968) 70 D.L.R. (2d) 149.

3s Building Products Ltd. v. B. P. Canada Ltd. [1961] Fox Pat. C. 130.

39 Cardwell v. Leduc \& Pelletier [1963] Ex. C. R. 207.

10 Including those passing-off actions in which the plaintiff encouraged the defendant to use certain of the plaintiffs distinctive names for similar products: See Cheerio Toys \& Games Ltd. v. Cheerio Yo-Yo \& Bo-Lo Ltd. (1964) 44 C.P.R. 169.

4 Dominion Companies Act: R.S.C. 1952, c. 53, 8. 25.

12 R.S.C. 1952, c. 215 .
} 
tion the application of which is prohibited by this Act. Thus the advertiser of jewelry and related products must present such products accurately in order that he remain within the definitions provided in the legislation.

The National Trade Mark and True Labelling Act ${ }^{43}$ in section 5 gives a regulatory power to the Governor-in-Council as to the "marking, labelling or advertising" of products coming within the Act. It also provides in sections 8(c), (d) and (e), generally, that false advertising of items bearing the national trade mark is prohibited. Its regulations generally define the form and manner in which the material content or quality may be described for such items as fur garments, textiles, hosiery, turpentine, chamois, and the jewel content of watches. The Act is administered by the Standards Branch of the Bureau of Consumer Affairs.

The Broadcast Act ${ }^{44}$ regulates advertising to the extent that the Board of Broadcast Governors can make regulations respecting the character of advertising. Presumably, they would regulate misleading advertising.

The Food and Drug Act ${ }^{45}$ provides that:

9(1) No person shall label, package, treat, process, sell or advertise any drug in a manner that is false misleading or deceptive or is likely to create an erroneous impression regarding its character, value, quantity, composition, merit or safety.

And in section 10(1) the Act provides that:

10(1) Where a standard has been prescribed for a drug no person shall label, package, sell or advertise any substance in such a manner that it is likely to be mistaken for such a drug, unless the substance complies with the prescribed standard.

The Act, in sections $5(1)$ and 6 respectively, contain the same provision for food, which is administered by the Food Division of the Standards Branch. This Branch undertakes a constant review of advertising in the press and broadcasting media. ${ }^{46}$ The main difference between this Act and the Combines Investigation Act is that here the advertiser would first be warned about his wrongdoing. In other words, the Consumer and Corporate Affairs Department works closely with industry to secure compliance under the Act and regulations.

It is noteworthy that in the United States, where the Food and Drug Administration has similar power over labelling, the Courts have held that "labelling" extends to many materials which would popularly be termed "advertising". ${ }^{47}$ However, the Canadian labelling provisions don't seem to be doing as well, as the Minister of Consumer and Corporate Affairs indicated when asked how soon there will be an ingredient listing on food products: 48

We will be introducing, during the present session ... a packaging and labelling bill which I hope will allow us to make more progress in this matter than has been made so far.

Although it prohibits certain advertising rather than merely restricting its misleading effect, the Hazardous Products Act ${ }^{49}$ should not go

\footnotetext{
is S. C. 1958, c. 22, a. 11(1) (c).

4 R.C.C. 1952, c 191.

es S. C. $1952-53$, c. 38.

46 It is interesting that the inspectors under the Food and Drug Act are also inspectors under the Broad. cast Act resulting in effective enforcement through both agencies.

17 (1966-67) 80 Harv. Law Rev. 1102.

10 Hansard, 4 February 1970, at 3206.

40 S. C. 196869, c. 42.
} 
unnoticed because of its significance in the control and regulation of advertising. It prohibits the advertising or sale of such things as furniture and other articles intended for children which are coated with paint containing harmful amounts of lead; varnishes and paints and varnish and paint removers for household use which are highly inflammable; jequirity beans or any substance or article such as toys or jewelry made from these poisonous beans.

Under this Act, which is administered by the Standards Branch of the Bureau of Consumer Affairs, advertising includes any representation by any means whatever for the purpose of promoting directly or indirectly the sale or other disposition of a hazardous product.

Thus, there are a number of remedies for misleading advertising both at common law and in the statutes. The competitor or consumer must choose his law wisely according to the basic principles outlined above for each law, and the government, if it is to curtail misleading advertising, must strictly enforce the provisions of section $33 \mathrm{D}$ of the Combines Investigation Act.

\section{SECTION 33D, COMBINES INVESTIGATION ACT MISLEADING ADVERTISING}

As previously stated, section $33 \mathrm{D}$ of the Combines Investigation Act, the most relevant of all legislation, has no reported cases since its transferral into the said Act which apply its law. ${ }^{50}$ However, in a letter to the writer dated 31 March 1970, D. H. W. Henry, the Director of Investigation and Research, sketched two test cases which have been completed, and noted that his department had laid two other charges under section 33D. 51

In each of the test cases, the accused pleaded guilty. One case involved a television advertisement for a device which was said to improve automotive performance and assist starting, and which, according to the tests made at the request of the Director of Investigation and Research, did not possess these properties. The second case concerned an advertised discount on gasoline which was given only as coupons for the purchase of other articles in the service station. With this scant information regarding cases under $33 \mathrm{D}$, no conclusions can readily be drawn, and, accordingly, it is desirable that government policy and intention be examined.

The transfer of the Criminal Code section to the Combines Investigation Act was effected on the basis of the recommendations of the Economic Council of Canada in its interim report on Consumer Affairs and the Department of the Registrar General, July, 1967, and also on the basis of the recommendations of the Special Joint Committee of the Senate and House of Commons on Consumer Credit (Prices) in its progress report of April 1967.

\footnotetext{
so As of 1 June 1970.

s1 Before said transferral, there were, as previously noted, no significant cases under the Criminal Code gection. There were, however, two interesting unreported Alberta cases: $R$. v. Trute Furriers Lid. and R. v. Cattle King Meats Ltd. In the former case, on 8 May 1968, Trute Furriers Ltd. were fined $\$ 50.00$ for a misleading advertisement which associated the name of Samuel Wiseman Fur Co., a reputable furrier, with the name of the accused. The Samuel Wiseman Fur Co., however, had gone out of businese and it was their name only which the owners of Trute used, and not the product as the edvertisement indicated. The latter case, heard on 8 January 1969, concerned a fly-by-night American concern and advertised cuts of freezer meats for a cheap price. It was a "bait and switch" deal where the customer never got what was advertised, but paid more for inferior quality meat. Unfortunately, the fines in each case were woefully small, being $\$ 50.00$ and $\$ 100.00$ respectively. Particular reason for not appealing the latter case was given as the absence of anyone in Alberta to whom to serve the Notice of Appeal, since the operators had flown by night.
} 
The Economic Council of Canada found that ${ }^{52}$

There is now no single unit in the Federal Government which is responsible for the co-ordinated enforcement of existing prohibitions against economic fraud and misrepresentation" contained in federal statutes

and the Joint Committee alluded to ${ }^{53}$

the need for an expert group within the Department (now the Department of Consumer and Corporate Affairs) to investigate any merchandising practices which take advantage of or mislead consumers.

While still on the topic of the incipient stages of 33D, it is noteworthy that the Canadian Advertising Advisory Board, referring to the clauses in section 33D, states that: 54

these clauses, now part of the Combines Investigation Act, were originally introduced at the request of the ethical business community; the honest businessman is the victim of the dishonest competitor just as is the consumer.

If this is true, it can be inferred that the honest businessman, rather than the government (or the latter at the instigation of the former) sought to establish s. 306 in the Code, and that the Department of Consumer Affairs is seeking to strengthen it by strict enforcement.

As mentioned earlier, it is government policy to interpret section 33D in such a manner as to prosecute as many offenders as possible. Further evidence of this governmental policy is found in the Department of Consumer and Corporate Affairs News Release, in which Hon. Ron Basford is quoted as saying: $: 5$

I'm glad that we can now exercise vigilance and fight deliberate attempts to dupe the public with misleading advertising. . . . If we find that the wording of the section is deficient, we will have no hesitation in preparing legislation that will do the job.

Mr. Basford also indicated that because of the lack of court cases dealing with the misleading advertising section, test cases will now be prepared with utmost care. The object, he continued, will be to test the limits of the law to determine its adequacy as a consumer protection measure. ${ }^{56}$

However, this object will not be effected by means of a strict bureaucratic structure. Referring to the administrative machinery, Mr. Basford said in 1968:57

I would hesitate to set up a huge bureaucratic machine with which each advertisement must be filed for approval before use. I can see such a procedure in certain sensitive areas, for example drugs, as is already the case. But for general advertising, I don't see the merit in it. A much better system is to have staff spot-check advertisements, and, when it sees an infraction, to lay a charge.

Now that the section has become law, the D.I.R. has :ublished

32 Economic Council of Canada, Consumer Affairs and the Department of the Registrar General, Interim Report (1967) at 25.

ss Special Joint Commission of the Senate and House of Commons on Consumer Credit (Prices), Progress Report (April, 1967) at 3452

s4 Advertising Today, supra, n. 7.

ss Department of Consumer and Corporate Affairs News Release (31 July 1969) at 2.

so Id. The Director of Investigation and Research has outlined the method used to test the limits of the law in his speech of 12 November 1969. subra. n. 12: "If after an inquiry there is, in the legal sense, a prima facie case, it will be referred to the Attorney General of Canada with a recommendation that proceedings be instituted in the courts. In a doubtful case, if our legal advice is that there is a reasonable chance that the Court will find that an offence has been committed, we will recommend that proceedings be instituted."

37 Financial Post, 9 November 1968, at A.55. 
certain categories as examples of advertising likely to be studied with enforcement of section 33D in mind. These categories are as follows: ${ }^{58}$

1. A misleading statement of fact in an advertisement

Example: "Below our cost" when the selling price is in fact higher than the delivered price of the article to the retailer.

2. A statement of performance which is not supported by an adequate test Example: Rope advertised as " 2,000 pound test" where no adequate and proper test of the rope has been made.

3. Deceptive use of contests

Example: "you are the lucky winner of our grand award" when in fact the "award" was not exceptional in that many people received the identical mailing piece.

4. "Free" offers that are not in fact free

Example: Receipt of the "free" gift is contingent on the purchase of another article or articles which could be purchased through conventional channels at lower prices.

5. "Bait-and-switch" operations where the item used as bait was not in fact held for sale by the advertiser. This is the practice of advertising an article at an exceptionally low price with the intention, not of selling that article but of switching customers to other goods.

6. Contest purporting to award prizes where such prizes are not in fact available Example: An advertiser announces planned distribution of $\$ 25,000$ in prizes but in fact does not provide for the distribution of prizes.

7. The "stuffed flat"

Example: An advertiser using the classified section purports to be selling his household furniture whereas in fact he is selling goods supplied from other sources.

8. "Clip-and-paste" solicitations

Example: This is a direct mail device in which typically the customer is invited to verify a listing in a directory but which when signed and returned amounts to an order for which he may be invoiced.

9. Misrepresentation as to origin Example: A manufacturer encloses a foreign made article in a display package marked "made in Canada".

Mr. Basford has emphasized that this list is neither final nor complete, and is receptive to comments on how they can be improved. ${ }^{59}$

Administration of the section with respect to the examination of advertising for possible infractions is carried out by members of the staff of the D.I.R. as an adjunct to the program established by 33C.60 In addition, the local offices of the Department across Canada will report any suspected violations to the Director, ${ }^{61}$ and close liaison is maintained with other federal agencies (e.g. Canadian Radio and Television Commission) which are concerned with advertising standards. Also, an effort will be made to co-operate with provincial consumer protection programs, and the Better Business Bureau. ${ }^{62}$ The Director of Investigation and Research, D. H. W. Henry, describes cooperation received in administering the section as follows: ${ }^{63}$

We . . have the cooperation and assistance of the R.C.M. Police in local areas, and are in process of developing liaison with the provincial authorities who, it must be remembered, also have jurisdiction through the provincial Attorney General to

ss (1969) Director of Investigation and Research Report.

so Supra, n. 55.

so Id. at 3.

so The Department is planning to decentralize its operation soon, however. There will be government ropresentatives in Vancouver, Winnipeg, Toronto, Montreal and Halifax, to investigate misleading advertising, rather than a staff only in Ottawa.

62 Supra, n. 60.

w Speech at Toronto, Ontario, 12 November 1969, supra, n. 12. 
enforce this legislation as well. We read newspapers (about 50 per cent of our section 33C cases are now detected by this method), we view television programs and radio broadcasts (our first conviction under section 33D arose in part out of a broadcast program).

We are developing liaison with the Canadian Radio and Television Commission and have already received cooperation from broadcasting stations in considering particular advertisements.

The Canadian Advertising Advisory Board, which publishes the Canadian Code of Advertising Standards, is co-operating with the Department. It has seen the value in section $33 \mathrm{D}$ and publishes it along with s. $33 \mathrm{C}$ and its own guides for advertising in the pamphlet containing their Code, which is readily available to the public.

Section $33 \mathrm{D}$ is a potentially effective one, particularly since the advertiser is subject to immediate prosecution rather than mere warnings, but its evaluation should follow closely the guidelines suggested by Handler: ${ }^{64}$

...the success of any program for the suppression of false and misleading advertising will depend upon (1) the adequacy of the definition of the offence; (2) the effectiveness of the penalties imposed; and (3) the efficacy of the methods of administration which are selected.

Concerning the definition of the offence, the same author has written: 65

The most serious defect in prior definitions has been the restriction of the prohibition to misrepresentation of fact... The shrewd use of exaggeration, innuendo, ambiguity and half-truth is more efficacious from the advertiser's standpoint than factual assertions... Any advertising legislation which leaves uncontrolled statements of opinion, puffs, exaggerated claims or ambiguous assertions imposes no real curb on the dishonest advertiser.

Does section 33D fulfill the requirements of a good definition? Although 33D(1) provides for a statement that purports to be a "statement of fact", read widely it could include anything which is not really a statement of fact (i.e. exaggeration, innuendo, etc.) but which the advertiser would have the consumer believe is a statement of fact. The phrase "intentionally so worded or arranged that it is deceptive or misleading" could apply to the nemisis described earlier, the Gestalt effect. In other words, this phrase leaves room for the advertisements which give a misleading effect, but which are composed of individually true statements.

Section $33 \mathrm{D}(2)$ deals with statements or guarantees of the performance, efficacy or length of life of products, all of which must be based upon a proper test. These are statements of fact, and the above guidelines for definition would not apply.

It could be argued that the only potential deception this section doesn't cover is opinion endorsements, but that, too could be caught by the above mentioned phrase in 33D(1): "...that purports to deal with a statement of fact but is intentionally so worded or arranged that it is deceptive or misleading."

It is impossible to assess the effectiveness of any penalties, as there have been none given. However, $33 \mathrm{D}(1)$ provides that anyone found guilty thereunder has committed an indictable offence and is liable to imprisonment for five years, and $33 \mathrm{D}(2)$ is a summary con-

\footnotetext{
of Handler, Trade Regulation, (1960) at 979.
}

es Id. at 982. 
viction offence. Although, judging from the results of actions brought under $33 \mathrm{C}$, there will probably be a substantial number of penalties and restraining orders given, it seems that the amounts of the summary conviction penalties are grossly inadequate- $\$ 100$ or $\$ 200$ would hardly be noticed even by a small specialty retail store. It is to be hoped that the courts, in applying $33 \mathrm{D}(1)$, will impose a significant penalty when they find the accused guilty, since the offence is indictable rather than summary.

The efficacy of the methods of administration cannot yet be properly evaluated, since this section, as mentioned before, has just come under the Combines Investigation Act in July, 1969. However, considering the list of areas for study already drawn up (supra) and the fact that the investigators are operating in conjunction with those who work under section $33 \mathrm{C}$ as well as with other government organizations and consumer protection concerns, it seems that the administration and enforcement of section $33 \mathrm{D}$ has a promising, efficacious future. 66

In summary, section $33 \mathrm{D}$, even though it was not significantly used when it was section 306 of the Criminal Code, appears to be a good piece of legislation in the cause of consumer (and competitor) protection, and it is hoped that the Department of Consumer and Corporate Affairs will be able to command enough funds and co-operation from the government to carry it out on a large scale. ${ }^{67}$

\section{SECTION 33C, COMBINES INVESTIGATION ACT-MISLEADING PRICE ADVERTISING}

33C. (1) Every one who, for the purpose of promoting the sale or use of an article, makes any materially misleading representation to the public, by any means whatever, concerning the price at which such or like articles have been, are, or will be, ordinarily sold, is guilty of an offence punishable on summary conviction. (2) Subsection (1) does not apply to a person who publishes an advertisement that he accepts in good faith for publication in the ordinary course of his business.

Among the statutory provisions relating to misleading advertising, section 33C of the Combines Investigation Act is probably the most important in terms of being directly on point and of being enforced. It was brought under the Act in 1960 for the purpose of controlling the retailer who represented to the public that his prices were lower than those of his competitors. ${ }^{68}$ The express intention of putting it into the Act was to "protect and improve the position of the independent merchant"69 according to the then Minister of Justice. Since it has been part of the Act, more than 80 cases have been placed before the courts.

\footnotetext{
60 Another factor contributing to the promising future of the administration aspect is the list of priorities noted by the Director of Investigation and Research in his speech of 12 November 1969, supra, $n$. 12 "With respect to section 33D which has just become part of the act, it is my intention to proceed in al cases where there appears to be a breach of the law, subject to the resources being available and the legal advice that 1 receive in particular cases. With limited resources, priorities will have to be assigned, certainly initially, based upon the following general principles. (a) The degree of coverage of the advertisement. (b) The impact of the advertisement on the public. (c) The deterrent effect of successful prosecution of a particular case. (d) The best cases to allow the courts to establish new principles and clarify the section."

67 See David Lewig' speech in Hansard, 23 January 1969, at 4760-1, for a plea for strong enforcement.

so See Hansard, 30 May 1960 , at 4349 .

69 Id.
} 
A report of the Director of Investigation and Research ${ }^{70}$ breaks down the offence in a logical manner. An offence under $33 \mathrm{C}$ is constituted when:

(1) there is a representation made (a) to the public, (b) for the purpose of promoting the sale or use (i.e. rental) of an article, and (c) concerning the price at which the article has been, or will be ordinarily sold; and

(2) such representation is materially misleading.

In $33 \mathrm{C}(2)$, however, there is an exception made for any publisher who accepts in good faith and publishes an advertisement in the ordinary course of his business. The provision carries a noticeable lack of protection for the advertisers and advertising agencies, while protecting the media. However, since many newspapers, radio stations, etc., have advertising departments whose function it is to compose advertisements for their customers (i.e., do the work of an advertising agency), the media could also be caught by this section.

A subsequent D.I.R. report, ${ }^{71}$ referring to section 33C, describes its effectiveness: ${ }^{72}$

After more than eight years of administration, in which many prosecutions have been successfully completed, the effectiveness of this legislation has been demonstrated. Misleading representations which have been the subject of prosecution have ranged from inflated price labels on mattresses to phony gift certificates on pots and pans... proceedings will be taken in appropriate cases against retailers as well as manufacturers.

The modus operandi under section $33 \mathrm{C}$ once the facts reach the D.I.R. (either through his staff who watch for violations in advertising materials ${ }^{73}$ or by complaints from the public) is to submit select information to the Attorney-General of Canada pursuant to section 15 of the Act. This must be done within six months, for it is a summary conviction offence (with a maximum penalty of $\$ 500$ fine, $\$ 1,000$ for corporations, or six months in prison or both, and, as provided by section 31(1) of the Act, a restraining Order) and section 693(2) of the Criminal Code requires that action be brought within six months of the offence. The D.I.R. Report for $1966-67$ properly points out that because of this limitation period it would be impractical to await a submission of a Statement of Evidence of the Restrictive Trade Practices Commission for a report.

Proceedings taken under section $33 \mathrm{C}$ are numerous ${ }^{74}$ The decisions, for the most part, have resulted in victory for the consumer's interests. The cases decided in favour of the advertiser have generally assumed that the consumer distinguishes between expressions such as "value", "list price" and "reg.". Whether these are valid distinctions in the eyes of the public, however, is moot; the decisions assume that the consumers are sophisticated and discerning, while textbook writers take the opposite view. In particular, Handler, in an

70 For the year ending 31 March 1968.

71 For the year ending 31 March 1969.

72 Id, at $50-51$.

${ }^{73}$ It is interesting that the members of the staff of the D.I.R. are trained to investigation, rather than in law or economics, and do a thorough job. See D.I.R. Report for 196869 at 51.

74 As previously mentioned, some 80 cases have been completed to date. For the following cases discussed in this paper, see D.I.R. Report for 1966-67 at 62-69; D.I.R. Report for 196768 at 5863; D.I.R. Report for $1968-69$ at 52.58 . 
appeal for greater legislative protection for the consumer, describes him as follows: ${ }^{75}$

...consumers are unsophisticated ... they unreasonably attach importance to baseless claims,... they are lurred by exaggerations, half-truths, ambiguities, and emotional appeals ... and (they) do not always act either wisely or reasonably.

The decisions referred to assume, on the contrary, that the public can distinguish that the following terms do not mean that the item was once sold at the higher price given: "value" and "comparable value"76 "list price" 77 and "special" when there is no reference on the label to another amount. ${ }^{78}$

Fortunately, however, most cases are decided for the protection of the consumer. Of all cases reported in the D.I.R. Report for 1969, the only ones which didn't end in conviction and/or an order prohibiting continuation of the offence were those with insufficient evidence. ${ }^{79}$ In those cases, phrases such as "retail", 80 "compare at" 81 and "special low price of", 82 where the prices referred to proved wrong, were held to be misleading.

There have been several noteworthy issues decided on section 33C, one of which is whether section $33 \mathrm{C}(1)$ represents one offence or three separate offences with the words "have been, are, or will be ordinarily sold." It was held in $R$. v. Morse Jewellers (Sudbury) $L t d .{ }^{83}$ that the section only created one offence, and that the different tenses are only used to give a comprehensive description. A later case on that same section held that it is one of strict liability and does not require a mens rea. ${ }^{84}$

Not infrequently, a retailer will advise a special and quote regular prices based on the manufacturer's suggested list prices, which regular prices are, of course, inflated over the usual price in the selling area of that retailer. Eddie Black's case ${ }^{85}$ held that "regular" is not synonymous with "suggested retail price" and following that decision, the Director of Investigation and Research has taken the position that the so-called regular price must be the price at which the goods have been sold by the majority of the dealers in the market in question..$^{86}$

Preticketing by the manufacturer is another area of interest under this section. If a manufacturer pretickets his goods at a higher cost than he thinks the public will pay in order to make them feel that they are getting a bargain when they see that the purchase price is less than the ticket price, he will be guilty of an offence under 33C.

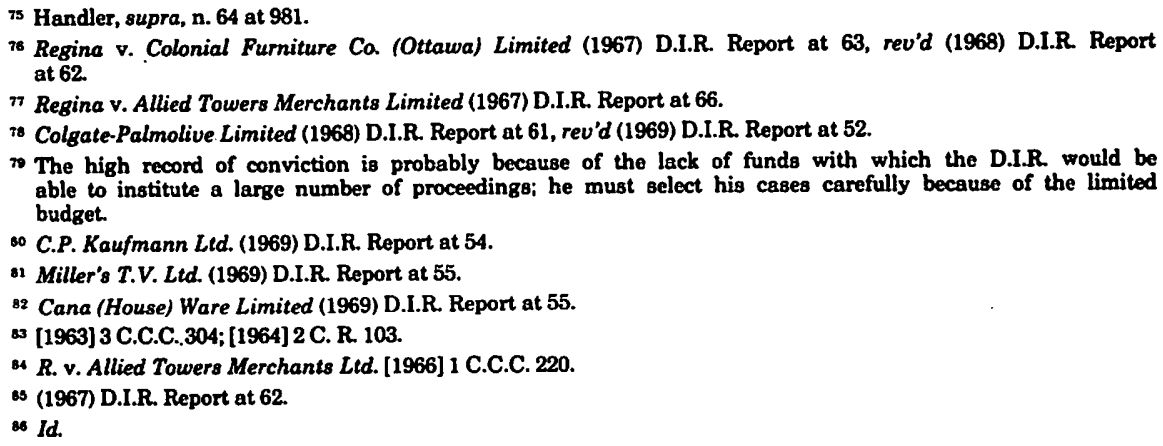


If, however, he believed that his product could reasonably be sold at the preticketed price, he will escape conviction. ${ }^{87}$

The cents-off cases under this section show that the representation on a label which advertises, e.g. 17థ off the regular price, when in fact the consumer is paying a price comparable to that charged by competitors, is illegal. Two cases, one in which the cents-off advertisement was on the label for four years (despite an upward change in price $)^{88}$ and the other which carried the same advertisement for three years ${ }^{89}$ held that not only does the length of time make the offenders guilty, but the fact that the ordinary shopper would believe he was getting cents off when, in fact he wasn't, also contributed to their guilt. This problem was discussed in the Joint Committee of the Senate and Commons which concluded that, while some cents-off deals are legitimate, the practice is so open to abuse that it should be ended. As a very minimum requirement, the Committee suggested that the regular price should be stated.90

Although there are many other lesser issues raised by the cases dealing with misleading price advertising, space does not permit a listing of these. However, there is one case which deserves special attention because it may be the harbinger of a new method of pricing goods in order to make the consumer's shopping easier. The Halo Shampoo case ${ }^{91}$ dealt with a situation in which the shopper had to calculate the price-per-ounce of shampoo for large and small bottles and compare them; often a complex task which would confuse even a mathematician with a slide rule. Although there was no order as to penalty, the Judge concluded that such a comparison would impose on the purchaser a burden to compare which is such a heavy burden that it is not contemplated within the wording of section $33 \mathrm{C}(1) .^{92}$

To summarize the law under this section in a practical manner, Mr. Orr of the Department of Consumer and Corporate Affairs, has produced a list of "don'ts" for advertisers:93

(a) Don't quote a comparative price without knowing your facts: it is not a defence for a person making the representation to show that he did not know that he had wrongly stated the ordinary price.

(b) Don't rely on manufacturers' list as a justification for "regular": the expression has been held to mean the price at which the article was sold in the area in which the representation was made, and for the same reason-

(c) Don't relay on a price in another area.

(d) Don't rely on the fact that the offer may represent good value: that is not the point in issue; it is whether the extent of the saving is accurately represented.

(e) Don't unquestioningly accept a representation originating with the manufacturer; if it is misleading, and if you pass it on by display on your shelves or by any other means you can be found guilty of the offence. In the Mountain Furniture case both the manufacturer who affixed the label to the mattress and the retailer who displayed it were convicted. This could happen equally where the representation was made on a label affixed, for example, to a bottle or jar, and retailers who continue to display items bearing misleading claims may very well find themselves before the courts.

\footnotetext{
${ }^{47}$ Regina v. Imperial Industries Led. (1967) D.I.R. Report at 64.

* Regine v. Produits Diamante Limited (1967) D.I.R. Report at 68.

89 Mother Parker's Tea and Coffee Limited (1968) D.I.R. Report at 59.

90 Financial Post, 9 November 1968, at A-55.

91 (1969) D.I.R. Report at 52.

22 Id.

93 Speoch to the Advertising Sales Club, Ottawa, 1970.
} 
(f) Don't believe that changing the expression without changing the idea provides a defence: use of expression such as "compare at", "was", "cents-off", "special", "save...", "value" have been held to convey to the consumer that the com. parison price so designated is that at which the article has been ordinarily sold. Remember the test:

(1) Would use of the expression lcad a shopper to believe that the comparison price quoted is that at which it is ordinarily sold?

(2) Is it true?

If you get answers yes and no respectively, it would not be wise to make the representation.

(g) Don't rely on ancient history. The comparison price should be one at which the article was sold in a period sufficiently recent as to have relevance, or in the case where the representation presents an introductory offer, the introduction should not be unduly prolonged.

\section{EXTRA-LEGAL ORGANIZATIONS}

Another area of consumer and "honest competitor" protection concerns the extra-legal organizations. The principal of these organizations is the Canadian Advertising Advisory Board, ${ }^{94}$ which is an all-industry body. It acts on behalf of the advertising industry in such matters as ethics, government and consumer relations, education, research and public information. Its main objectives, as reproduced in its pamphlet containing the Canadian Code of Advertising Standards, are:

(a) to develop, promote and encourage adherence to approved national advertising standards and practices, including the 'Canadian Code of Advertising Standards'; (b) to contribute to the continuing improvements of advertising effectiveness by assisting in the development of appropriate educational and training programs; (c) to sponsor and support research into advertising, including its social and economic effects;

(d) to improve public awareness of the contributions of advertising to Canada's economic and social well being, and

(e) to serve the common interests of the Canadian advertising industry.

The C.A.A.B. describes its own function and origin, as well as the proper course of action a consumer should take when he finds what he feels to be a misleading advertisement: 95

94 A glance at the members of the Board gives the inquirer an indication of its influence and importance: Corporate Members:

Association of Canadian Advertisers

Canadian Association of Brosdcasters

Canadian Business Press

Canadian Daily Newspaper Association

Institute of Canadian Advertising

Magazine Advertising Bureau

Outdoor Advertising Association of Canada

Trans-Ad Division, Wamock Hersey International

Associate Members:

Agricultural Press Association of Canada

American Marketing Association-Toronto Chapter

Canadian Direct Mail Association

Federation of Canadian Advertising and Sales Clubs

Industrial Marketers of Toronto

Radio Sales Bureau

Television Bureau of Canada

The Canadian/Star Weekly

Weekend/Perspectives

Not only does this list convey to the observer the power which the C.A.A.B. wields, but it also demonstrateg the many and diverse advertising associations existent. Also, an additional indication of its influence can be found in the fact that in the six month period ending 31 March 1970, it distributed over 54,000 copies of the Canadian Code of Advertising Standards, and dealt with nearly 800 complaints. Of these complaints (disregarding those respecting business practice outside advertising and moral judgement) the Board ruled on 468, and 59 were sustained as Code infringements with corrective action following in each instance.

${ }^{95}$ Advertising Today, supra, n. 7. The Advertising Standards Council seems to investigate all complaints sent in by the public. The writer complained about a misleading television advertisement, and very soon afterwards received a reply asking whether the ad was national or local, in order that they could investigate further. 
The business community... realizes that everyone suffers when a few offenders try to defraud the public. More than 50 years ago, the Association of Canadian Advertisers and the Federation of Advertising and Sales Clubs helped to found the Better Business Bureau, to act in the consumer's interests. Many media associations, the media themselves, and large retail outlets have their own code of what is acceptable, and the Canadian Code of Advertising Standards has been adopted by the Association of Canadian Advertisers, by the Institute of Canadian Advertising (representing advertising agencies) and by all national media associations. If you feel an advertisement is misleading write to the advertiser or the medium that carried the message. If you do not get a satisfactory answer, write to the Advertising Standards Council.

This view is indeed an encouraging one, and disspells to an appreciable extent many doubts which the average consumer probably has of the advertising industry.

The Canadian Code of Advertising Standards, prepared by the C.A.A.B. and mentioned in the above reference, is of particular interest since it is widely advertised and is the Board's method of discovering the complaints of the public. It is approved in principle by all of the corporate members of the C.A.A.B. as well as the Association of Canadian Better Business Bureau Inc., Association of Industrial Advertisers, the C.B.C., Canadian Weekly Newspaper Association and the Periodical Press Association, all of which serve to represent a substantial piece of the Canadian Advertising Industry.

The Code was formed in 1963 and revised and re-published by the C.A.A.B. in 1967. The Board established supervising bodies, which are the Advertising Standards Council (English) and the Conseil des Normes de Publicite (French). They act principally as arbiters to ensure that the Code is followed. The revised edition of the Code has the following provision for misleading advertising:

No advertisement shall be prepared, or be knowingly accepted, which contains false, misleading, unwarranted or exaggerated claims-either directly or by implication.

Advertisers and advertising agencies must be prepared to substantiate their claims.

This provision, were it law, would comply almost completely with Handler's requirements discussed earlier.96 It contains the words "unwarranted" and "exaggerated", and uses the word "claim" rather than "statement of fact". It is therefore wide enough to catch advertisements based on opinion rather than upon statement of fact.

The C.A.A.B. describes in the same pamphlet how complaints are handled:

Each complaint arising from alleged violations of the Code is explored and if a breach of Code Standards is indicated, direct contact is made with the advertiser in an effort to correct the infraction. In most cases this results in voluntary compliance.

If agreement is not reached, the case is reviewed by the Advertising Standards Council which decides on the action necessary to secure adequate correction. The advertiser is notified of the Council's decision and requested to make any change required.

There are, of course, cases in which the advertiser may not agree to comply. In such an event, the media groups (who are among the sponsors of the C.A.A.B., its Advertising Standards Council(s) and the Advertising Code) are advised not to accept the advertisement until a correction is made. R. E. Oliver, President of the C.A.A.B., states in a letter to the writer dated 3 June 1970 that there have been only two instances, both of which concerned small retail outlets, where the

o6 See accompanying text, supra, n. 64. 
advertiser was unprepared to take corrective action. In both cases, the media took immediate corrective action, cancelling one copy and amending the other.

The penalty, therefore, is similar to an order prohibiting continued use of the advertisement, which is done under section 33C and 33D of the Combines Investigation Act. The advertiser, being deprived of the use of normal advertising outlets, would be restrained from reaching the public with his misleading message.

Before leaving the area of voluntary controls by the advertising profession, a cursory look at the American advertising profession, and comment, is beneficial. Similar to its counterpart in Canada as just outlined, 97

...the advertising profession appreciates the inadequacy of any definition which is confined to statement of fact... The Association of National Advertisers and the American Association of Advertising agencies in 1932 declared that...

The following copy practices are unfair to the public and tend to discredit advertising.

1. False statements or misleading exaggerations;

2. Indirect misrepresentation of a product, or service, through distortion of details, either editorially or pictorially ...

3. Price claims that are misleading...

That this is analogous to the Canadian Code in its False or Misleading Advertising section, and its Bait advertising section ${ }^{98}$ is obvious. Therefore, the author's further statement that ${ }^{99}$

It is within the power of advertising media to prevent any deceptive advertising. also applies. In fact, it would apply whether or not the C.A.A.B. published the Code, but since we do have a similar Code, the case for comparison is stronger.

Therefore, industrial, extra-legal controls seem to effectively curb misleading advertising. The provisions cited are generally wider than $33 \mathrm{D}(1)$ and (2) in the Combines Investigation Act, with the one exception that the Act includes rental ("use") of items while the Code does not specifically state this-although it could be implied.

With the support of the organizations listed, however, the logical conclusion is that the industry (excepting the dishonest advertiser) is just as interested in controlling misleading advertising as is the government. To buttress this conclusion and show that extra-legal organizations and the government are working together, Mr. Oliver has stated:100

... I cleared this campaign concept with the Department of Consumer and Corporate Affairs before any of the current advertisements were prepared, as we did not want them to feel we were 'in competition' with them. Where, in their opinion, advertising is misleading, the Department, of course, has a clear duty to prosecute. On the other hand, we find that most of the justified complaints (though certainly not all) seem to result from inept communication. In addition, there are many ethical areas, where the consumer in our view has a legitimate complaint, even though the message may be legally correct. In such instances, we are able to play a supplementary role, and often can bring about correction within a matter of days-sometimes within hours. Indeed, because we can operate on a "judgment" basis, without going through

\footnotetext{
97 Handler, supra, n. 64 at 983.

as "No advertisement shall be prepared, or be knowingly accepted, which does not give the consumer a fair opportunity to purchase the goods or services advertised at the terms or prices represented."

\% Handler, supra, n. 64 at 983.

100 In the aforementioned letter to the writer.
} 
the due process of law, it seems reasonable to suppose that this voluntary cooperative industry response from a community point of view usually saves both time and money.

Naturally, there are also many instances where the community is better served through legal recourse and appropriate penalties. I did tell the Department that our concern was correction, not prosecution, and that we felt no obligation to notify them of sustained cases. We have, however, on more than one occasion asked Government officials to investigate where we felt a deliberate and clever attempt was being made to stay within the law but to con the consumer nonetheless.

\section{CONCLUSION}

It was been found to be that advertising, the major tool of such fields as business, policies and religion, and an indispensible asset to the consumer, is subject to the machinations of the dishonest advertiser. He misuses it either by means of subtleties and carfully worded phrases, or else by means of blatant untruths. He relies on the unsophistication of some consumers and the passivity of others in order to promote his product with false claims.

Not only is his dishonesty a detriment to the unsuspecting public, who seldom have the facilities or the ambition to test products or to compare prices, but it is also a plague on the honest advertiser, who seeks a steady, reliable market by means of reliable advertising.

Despite the common law, the statutory law (particularly the provisions contained in $33 \mathrm{C}$ and $33 \mathrm{D}$ of the Combines Investigation Act) and the voluntary controls imposed upon industries by themselves through the C. A. A. B., the problem of misleading advertising is a difficult one to mitigate, let alone eradicate. Most companies responsible for much of the deceptive advertising are either national, or even worse, foreign owned subsidiaries of giant multi-national corporations. In the latter case, if an advertising policy is set in the United States, for example, then although their specific advertisements in Canada are subject to the jurisdiction of the Combines Investigation Act, and other relevant law, the following could happen: (1) If a fine were levied under $33 \mathrm{C}$, a summary offence, the sum would be miniscule in relation to the profits the company may be making as a result of the advertisement in question; or (2) If a restraining order was given, the company, while pursuing the same U.S. based policy, could alter their ad, but would probably alter it to be in keeping with the same policy, and not necessarily make their representations honest.

The above two considerations, of course, would also apply to large national Canadian advertisers, but the second consideration would be more able to be controlled by indirect sanctions.

In order to control misleading advertising effectively, it is submitted that: (a) the Combines Investigation Act increase the maximum penalties under 33C and 33D so that they are both indictable offences with a maximum cash penalty in the neighbourhood of at least $\$ 50,000^{101}$ so the Act will have the effect of strict penal legislation; (b) the budget for administering this section be generous. Considering the amount spent on advertising, this does not seem to be an unreasonable proposal; (c) section 33D be amended in order that its terms are broader and that

101 Although this is an expense which may be passed on to the consumer, in view of the competitive price eystem it is doubtful that a penalized company will raise the price of its products and risk losing even more money because purchasers belect the less expensive item. 
it fits in with Handler's definition, as does the description of misleading advertising in the Advertising Standards Code. ${ }^{102}$ The less loopholes in the Act, the easier it will be to enforce.

As shown in the text of this paper, concern for misleading advertising is growing not only among business competitors and the consumer, but also in the government. If this trend continues, there is indeed an optimistic future for the control of misleading advertising. To paraphrase a well-worn statement:

You can mislead all of the people some of the time and some of the people all of the time, but not all of the people all of the time.

It is to be hoped that advertising will mislead none of the people at any time.

102 It should be noted that Mr. Orr's speech, supra, n. 93, sugrested that their lezal department was already working on specific areas dealing with the section. For example, he noted that "our legal branch will be asked to study the question of whether, in given circumstances, a verbal statement delivered personally to prospective buyers by salesmen acting on their principal's instructions might be held to come within the meaning of the section." 